\title{
Fecundity of Uca uruguayensis and Chasmagnathus granulatus (Decapoda, Brachyura) from the "Refugio de Vida Silvestre" Bahía Samborombón, Argentina
}

\author{
César, II. ${ }^{\mathrm{a}, \mathrm{b} *}$, Armendáriz $L C$. $^{\mathrm{a}}$ and Becerra, $R V^{\mathrm{a}}$ \\ aDivisión Zoología Invertebrados, Facultad de Ciencias Naturales y Museo, \\ Universidad Nacional de La Plata - UNLP, Av. Paseo del Bosque, s/n, 1900 La Plata, Argentina \\ ${ }^{\mathrm{b}}$ Investigador CIC \\ *e-mail: icesar@fcnym.unlp.edu.ar
}

Received February 9, 2006 - Accepted June 7, 2006 - Distributed November 30, 2007

\begin{abstract}
The aim of the present work conducted at the Refugio de Vida Silvestre Bahía Samborombón is to analyse the most relevant aspects of the fecundity of Chasmagnathus granulatus and Uca uruguayensis. Samplings were carried out from March 2001 to February 2003. Ovigerous females of U. uruguayensis $(\mathrm{N}=13)$ and C. granulatus $(\mathrm{N}=25)$ were found during spring and summer, their sizes $(\mathrm{CW})$ varied from 9.1 to $11.7 \mathrm{~mm}$ for the former species and from 22.8 to $32.4 \mathrm{~mm}$ for the latter. The egg diameter in $U$. uruguayensis ranged from 245 to $260 \mu \mathrm{m}$ for embryos in the early stage of development and from 250 to $345 \mu \mathrm{m}$ for those in mid-developmental stage, while in C. granulatus from 250 to $345 \mu \mathrm{m}$ and from 260 to $365 \mu \mathrm{m}$ respectively. Fecundity varied from 1126 to 6745 eggs/brood in $U$. uruguayensis and 15688-57418 eggs/brood in C. granulatus. For those females with broods in mid-developmental stage, several relationships were made. For $U$. uruguayensis the best correlation coefficients were obtained for the relationships: female weight vs. egg mass weight and carapace width vs. egg mass weight; for $C$. granulatus the best association was obtained between female size and the egg number and the egg mass weight.
\end{abstract}

Keywords: fecundity, Uca uruguayensis, Chasmagnathus granulatus, Argentina.

Fecundidade de Uca uruguayensis e Chasmagnathus granulatus (Decapoda, Brachyura) no "Refúgio de Vida Silvestre” Bahía Samborombón, Argentina

\begin{abstract}
Resumo
O objetivo do presente trabalho foi analisar os aspectos mais relevantes da fecundidade de Chasmagnathus granulatus e Uca uruguayensis no Refúgio da Vida Silvestre Bahia Samborombón. As amostragens foram realizadas de março de 2001 a fevereiro de 2003. As fêmeas ovígeras de $U$. uruguayensis $(\mathrm{N}=13)$ e de $C$. granulatus $(\mathrm{N}=25)$ foram capturadas na primavera e verão. A largura da carapaça (LC) de U. uruguayensis variou de 9.1 a $11.7 \mathrm{~mm}$, e de 22.8 a $32.4 \mathrm{~mm}$ para $C$. granulatus. O diâmetro dos ovos de U. uruguayensis variou de 245 a $260 \mu \mathrm{m}$ para embriões em estágio de desenvolvimento inicial e de 250 a $345 \mu \mathrm{m}$ para aqueles em estágio intermediário; para C. granulatus as variações foram de 250 a $345 \mu \mathrm{m}$ e de 260 a $365 \mu \mathrm{m}$, respectivamente. A fecundidade de $U$. uruguayensis variou de 1126 a 6745 ovos/desova e para C. granulatus de 15688 a 57418 ovos/desova. Para as fêmeas com massa de ovos em estágio de desenvolvimento intermediário foram efetuadas várias relações: para $U$. uruguayensis os melhores coeficientes de correlação foram obtidos nas relações: peso da fêmea vs. peso da massa de ovos, e largura da carapaça vs. peso da massa de ovos. Para C. granulatus, a melhor associação foi obtida entre o número de ovos e o peso da massa de ovos.
\end{abstract}

Palavras-chave: fecundidade, Uca uruguayensis, Chasmagnathus granulatus, Argentina.

\section{Introduction}

The reproductive aspects and fecundity in brachyurans from the Neotropical region has been treated for different families, among them Portunidae (Mantelatto and Fransozo, 1997), Grapsidae and Varunidae (Spivak et al., 1996; Luppi et al., 1997; Conde et al., 2000; Leme, 2002, 2004), and Ocypodidae (Spivak et al., 1991; Costa et al., 2006). These papers refer mostly to Brazil and the Mar

Chiquita Lagoon (Argentina). From them it can be appreciated that reproductive aspects are adaptive processes intimately related with environmental conditions, such as latitude, temperature, larval food availability, giving a single species a continuous reproduction in tropical areas of its distribution and a seasonal one in the temperate zones (Spivak et al., 1991; César et al., 2005; Costa et al., 2006). 
Chasmagnathus granulatus Dana, 1851 (Varunidae) and Uca uruguayensis (Nobili, 1901) (Ocypodidae) are two endemic species of crabs recorded in the template biogeographic region of the southwestern Atlantic Ocean. The former inhabit estuaries, Spartina sp. salt-marshes, halophyte meadows and mangroves from Río de Janeiro (Brazil) to the Río Negro River (Argentina), while the latter is found as far as Quequén River (Buenos Aires, Argentina). Both species occupy the high levels of the silty or silt-sandy intertidal ecosystem (Spivak et al., 1991; Spivak, 1997a, 1997b) and are semi-terrestrial species that build burrows and use the habitat in a rather complex way. Very dense populations of $C$. granulatus and $U$. uruguayensis inhabit the intertidal ecosystem of Samborombón Bay (César et al., 2005), giving to the landscape a special physiognomy called "cangrejales". The southernmost permanent populations of U. uruguayensis inhabits Samborombón Bay, however some intermittent populations are found in the Mar Chiquita coastal lagoon, $250 \mathrm{~km}$ further south (Spivak et al., 1991). The Samborombón Bay includes the socalled "depression of the Salado river" that extends from Punta Piedras $\left(35^{\circ} 30^{\prime} \mathrm{S}\right.$ and $\left.56^{\circ} 45^{\prime} \mathrm{W}\right)$ to Cabo San Antonio ( $36^{\circ} 22^{\prime} \mathrm{S}$ and $\left.57^{\circ} 23^{\prime} \mathrm{W}\right)$. This bay is a depocentre of significant magnitude, formed by clayish sediments from the sea and the Uruguay and Paraná rivers generating coastal plains with large marshes (Violante et al., 2001). The coast of the bay is bathed by salty waters of variable salinity corresponding to the estuarine area of the Río de la Plata River (Boschi, 1988).

The aim of the present work conducted at the "Refugio de Vida Silvestre" Bahía Samborombón was to analyse the most relevant aspects of the fecundity of these two crab species.

\section{Material and Methods}

Sampling was conducted during each season (three occasions in spring and two in the other seasons) be- tween March 2001 and February 2003 at the mouth of Channel 1 at the Refugio de Vida Silvestre Bahía Samborombón ( $36^{\circ} 16^{\prime} \mathrm{S}$ and $\left.57^{\circ} 06^{\prime} \mathrm{W}\right)$. Ovigerous females were collected by hand using a square of $5 \mathrm{~m} \times 5 \mathrm{~m}$, with $0.5 \mathrm{~m} \times 0.5 \mathrm{~m}$ subunits $(\mathrm{N}=10)$ following Elliott (1983). In September 2001, October and December 2002 five ovigerous females of $C$. granulatus were collected just beside the square. The crabs were kept in plastic bags and frozen. On each sampling occasion physicochemical variables were measured (using the Checkmate Modular Testing system by Ciba Corning Analytical): temperature $\left({ }^{\circ} \mathrm{C}\right), \mathrm{pH}$, and conductivity, then salinity was obtained after multiplying the conductivity by 0.9 ; due to difficulties with the equipment only the measure of conductivity and $\mathrm{pH}$ could be taken in winter. In the laboratory, crabs were thawed at room temperature and fixed in $10 \%$ formalin. Total carapace widths $(\mathrm{CW})$, wet and dry weight $\left(60^{\circ} \mathrm{C}\right.$, during 48 hours) were measured. The dry weights of the brooded egg mass and number of eggs per brood (extrapolated from the dry weight of a counted sub-sample of 1000 eggs) were measured in order to determine the brood size (Hines, 1982; Mantelatto and Fransozo, 1997; Luppi et al., 1997; Leme, 2004). Although some authors (Mantelatto and Fransozo, 1997) recommend the use of embryos in developmental stages from late blastula to early gastrula for fecundity analysis, to avoid effects of embryonic diameter swelling during late stages of development, we considered here (following Hines, 1982; Luppi et al., 1997; Leme, 2004) also those embryos in the intermediate stage of development, as determined by formation of eyes.

\section{Results}

The registered physical and chemical variations are typical of an estuarine ecosystem and are shown on Table 1.

In both species the ovigerous females captured presented broods with embryos in early and intermedi-

Table 1. Physical and chemical variables measured at sites sampled on Channel 1, Bahía Samborombón. The salinity values were obtained after multiplying the conductivity by 0.9 .

\begin{tabular}{cllll}
\hline Season & $\mathbf{T}\left({ }^{\circ} \mathbf{C}\right)(\mathbf{x} \pm \mathbf{S D})$ & $\begin{array}{c}\text { Conductivity } \\
\left(\mu \mathbf{S . c m}^{-1}\right)(\mathbf{x} \pm \mathbf{S D})\end{array}$ & $\begin{array}{c}\text { Salinity } \\
\left(\mathbf{m g . L ^ { - 1 } )}(\mathbf{x} \pm \mathbf{S D})\right.\end{array}$ & $\mathbf{p H}(\mathbf{x} \pm \mathbf{S D})$ \\
\hline \multirow{2}{*}{ Summer } & $27.3 \pm 2.68$ & $4790 \pm 2349.55$ & $4311 \pm 2114.59$ & $8.41 \pm 0.29$ \\
& $\min : 23.8$ & $\min : 3210$ & $\min : 2889$ & $\min : 8.09$ \\
& $\max : 29.6$ & $\max : 7490$ & $\max : 6741$ & $\max : 8.68$ \\
Autumn & $16.53 \pm 0.72$ & $828.50 \pm 190.21$ & $745.65 \pm 171.19$ & $8.39 \pm 0.51$ \\
& $\min : 15.7$ & $\min : 694$ & $\min : 624.6$ & $\min : 8.03$ \\
Winter & $\max : 17$ & $\max : 963$ & $\max : 866.7$ & $\max : 8.76$ \\
& $13.5 \pm 4.94$ & - & - & - \\
\multirow{2}{*}{ Spring } & $\min : 10$ & 675 & 607.5 & 8.97 \\
& $\max : 17$ & - & - & - \\
& $25.46 \pm 4.18$ & $981.87 \pm 75.59$ & $883.68 \pm 68.03$ & $8.14 \pm 0.32$ \\
& $\min : 19.3$ & $\min : 857$ & $\min : 771.3$ & $\min : 7.82$ \\
& $\max : 30.7$ & $\max : 1088$ & $\max : 979.2$ & $\max : 8.77$ \\
\hline
\end{tabular}


ate stages of development. Ovigerous females of $U c a$ uruguayensis $(\mathrm{N}=13)$ were found in December 2001 $(\mathrm{N}=2)$, December $2002(\mathrm{~N}=4)$ and February 2003 $(\mathrm{N}=7)$. The sizes $(\mathrm{CW})$ of the smallest and biggest individuals were 9.1 and $11.7 \mathrm{~mm}$, respectively, and their brood sizes varied from 1126 to 6745 eggs /brood $(\mathrm{X} \pm \mathrm{SD}=3338.58 \pm 1758.86)$. The egg diameter ranged from 245 to $260 \mu \mathrm{m}(\mathrm{X} \pm \mathrm{SD}=253.25 \pm 4.66)$ for embryos in the early stage of development and from 250 to $300 \mu \mathrm{m}(\mathrm{X} \pm \mathrm{SD}=285.97 \pm 15.07)$ for embryos in middevelopmental stage. For those females with broods in mid-developmental stage, the following relationships were analysed: carapace width vs. number of eggs, carapace width vs. brood dry weight, female wet weight vs. brood dry weight, brood dry weight vs. number of eggs and finally, female wet weight vs. number of eggs (see Table 2).

Ovigerous females of $C$. granulatus $(\mathrm{N}=25$, one of them, with zoeas about to hatch, was not considered in the analysis) were found on the same date reported for the former species ( $\mathrm{N}=7$ on December 2001, $\mathrm{N}=8$ on December 2002, $\mathrm{N}=8$ on February 2003) and also on September $2001(\mathrm{~N}=1)$ and October $2002(\mathrm{~N}=1)$. Sizes of these individuals ranged from 22.8 to $32.4 \mathrm{~mm}$. The sizes of the broods varied from 15688 to 57418 eggs/ brood $(\mathrm{X} \pm \mathrm{SD}=31371.08 \pm 10217.23)$. The egg diameter ranged from $250-345 \mu \mathrm{m}(\mathrm{X} \pm \mathrm{SD}=287.10 \pm 20.33)$ for embryos in the early stage and 260-365 $\mu \mathrm{m}$ $(\mathrm{X} \pm \mathrm{SD}=314.05 \pm 24.89)$ for embryos in the intermediate stage of development. The above mentioned relationships between carapace width, female wet weight, brood dry weight and number of eggs were also determined for C. granulatus (Table 2).

\section{Discussion}

The "cangrejal" studied is inhabited by large populations of C. granulatus and U. uruguayensis which coexisted in Samborombón Bay, building their burrows in close proximity to one another (César et al., 2005). They were active during the period studied, except in July 2002 when no individuals from either species were recorded in their burrows (at least up to $50 \mathrm{~cm}$ deep) or on the surface. This could be due to climate factors, in particular to the frequent frosts registered during that winter. Many brachyurans diminish their activities during the most rigorous seasons of the year and remain apparently inactive, dug into their burrows or hidden inside of crevices of trees. Such behaviour was also reported by Spivak et al. (1996) for C. granulatus in the Mar Chiquita lagoon and for Aratus pisonii (H. Milne Edwards, 1837) in the mangroves of São Paulo State, Brazil (Leme, 2002).

Ovigerous females of $U$. uruguayensis were found in summer, Spivak et al. (1991) also found ovigerous females of this species in Mar Chiquita lagoon in summer but in higher percentages than ours. Although the population studied in Samborombón Bay has a high density (César et al., 2005), the fact of having collected a low number of ovigerous females could be due to a differential behaviour during this incubation period. Costa et al. (2006) captured the ovigerous females very deep in their burrows and suggested that this species would not feed during this period. On the other hand, U. uruguayensis presented continuous reproduction throughout the year in the north limit of its distribution (Brazil), while in the south (the population here studied in Samborombón Bay and the one studied by Spivak et al., 1991 in Mar

Table 2. Regression analysis of fecundity in Uca uruguayensis and Chasmagnathus granulatus in intermediate stage of development (r: correlation coefficient; Fe: number of eggs; CW: carapace width; WBW: wet body weight of ovigerous female; DWB: dry weight of broods); $(*, * *$ : regression coefficient significantly different from zero $\mathrm{P}<0.05,<0.01$, respectively, ns: statistically not significant $\mathrm{P}>0.05$ ).

\begin{tabular}{|c|c|c|c|}
\hline \multicolumn{4}{|c|}{ Uca uruguayensis $(\mathrm{n}=11)$} \\
\hline Relation & $\begin{array}{c}\text { Power } \\
\mathbf{Y}=\mathbf{a} \mathbf{X}^{\mathbf{b}}\end{array}$ & $\begin{array}{c}\text { Log-Log Transformation } \\
\ln Y=\ln a+b \ln X \\
\end{array}$ & $\mathbf{r}$ \\
\hline Fe vs. CW & $\mathrm{Fe}=2.4303 \times 10^{-3} \mathrm{CW}^{2.9982}$ & $\ln \mathrm{Fe}=-6.0197+2.9982 \ln \mathrm{CW}$ & $0.5076 \mathrm{~ns}$ \\
\hline DWB vs. CW & $\mathrm{DWB}=2.0434 \times 10^{-4} \mathrm{CW}^{2.5149}$ & $\ln \mathrm{DWB}=-8.4957+2.5149 \ln \mathrm{CW}$ & $0.9620 *, * *$ \\
\hline DWB vs. WBW & $\mathrm{DWB}=0.1671 \mathrm{WBW}^{0.8091}$ & $\ln \mathrm{DWB}=-1.7887+0.8091 \ln \mathrm{WBW}$ & $0.8795 *, * *$ \\
\hline Fe vs. DWB & $\mathrm{Fe}=61.0565 \mathrm{DWB}^{1.1933}$ & $\ln \mathrm{Fe}=4.1118+1.1933 \ln \mathrm{DWB}$ & $0.5282 \mathrm{~ns}$ \\
\hline Fe vs. WBW & $\mathrm{Fe}=12.8442 \mathrm{WBW}^{1.5019}$ & $\ln \mathrm{Fe}=2.5529+1.5019 \ln \mathrm{WBW}$ & $0.7226 *$ \\
\hline \multicolumn{4}{|c|}{ Chasmagnathus granulatus $(\mathrm{n}=18)$} \\
\hline Relation & $\begin{array}{c}\text { Power } \\
\mathbf{Y}=\mathbf{a} \mathbf{X}^{\mathbf{b}} \\
\end{array}$ & $\begin{array}{c}\text { Log-Log Transformation } \\
\ln Y=\ln a+b \ln X \\
\end{array}$ & $\mathbf{r}$ \\
\hline Fe vs. CW & $\mathrm{Fe}=3.1739 \times 10^{-5} \mathrm{CW}^{2.4131}$ & $\ln \mathrm{Fe}=-4.4984+2.4131 \ln \mathrm{CW}$ & $0.4984 *$ \\
\hline DWB vs. CW & $\mathrm{DWB}=1.4269 \times 10^{-9} \mathrm{CW}^{1.9874}$ & $\ln \mathrm{DWB}=-8.8456+1.9874 \ln \mathrm{CW}$ & $0.4501 \mathrm{~ns}$ \\
\hline DWB vs. WBW & $\mathrm{DWB}=2.1272 \times 10^{-4} \mathrm{WBW}^{0.6259}$ & $\ln \mathrm{DWB}=-3.6722+0.6259 \ln \mathrm{WBW}$ & $0.5648 *$ \\
\hline Fe vs. DWB & $\mathrm{Fe}=2.8536 \times 10^{-6} \mathrm{DWB}^{0.9528}$ & $\ln \mathrm{Fe}=-5.5446+0.9528 \ln \mathrm{DWB}$ & $0.8689 *, * *$ \\
\hline Fe vs. WBW & $\mathrm{Fe}=86.7560 \mathrm{WBW}^{0.6448}$ & $\ln \mathrm{Fe}=1.9383+0.6448 \ln \mathrm{WBW}$ & $0.5307 *$ \\
\hline
\end{tabular}


Chiquita Lagoon, both in Argentina), its reproduction was seasonal.

In the case of $C$. granulatus, the ovigerous females were found in spring and summer, such as reported by López Greco and Rodríguez (1999) at "Faro San Antonio" beach, at the southern point of Samborombón Bay. Also Spivak et al. (1996) reported for this species in Mar Chiquita Lagoon a seasonal reproduction during spring and summer.

In brachyuran crabs fecundity is related to female size, latitudinal distribution and habitat adaptations. For the organisms that develop in similar environments, female size and the volume of the body cavity appear to limit the brood size, being these features the main factors to determine fecundity and reproductive effort (Hines, 1982; Thurman, 1985; Mantelatto and Fransozo, 1997).

The effective fecundity expressed as the number of eggs per brood would be related as mentioned above, to the different kinds of environments and to the female sizes. Thus, in the Uca species from intertidal brackish environments, such as U. triangularis (Milne-Edwards, 1873), U. annulipes (Milne-Edwards, 1837) and $U$. rapax (Smith, 1870), fecundity varied among 3390, 6400 and 28500 eggs/brood respectively, being their average sizes $9.6,11.3$ and $15.8 \mathrm{~mm}$ of carapace width (Thurman, 1985). On the other hand, the population of U.uruguayensis studied by Costa et al. (2006) in Ubatuba, Brazil, presented a lower fecundity (mean fecundity: $1883 \pm 490$ eggs) than the population here studied, which is related to the smaller size in the ovigerous females captured $(\mathrm{C} . \mathrm{W}=6.6 \pm 0.8 \mathrm{~mm})$.

In $C$. granulatus the effective fecundity was similar to that recorded in the Mar Chiquita by Luppi et al. (1997), though a bit lower than that determined by Botto and Irigoyen (1979) for the population at Salado river. Other grapsoids studied showed the association mentioned between fecundity and female size, thus Cyrtograpsus angulatus exhibited similar values to that of C. granulatus, and Aratus pisonii lower ones (Luppi et al., 1997; Conde et al., 2000). In the case of Sesarma rectum Randall, 1840, C. granulatus presented a higher fecundity but the eggs of the former species were almost double in size (Leme, 2004).

In $U$. uruguayensis the correlation coefficients for the relationship of female weight with egg mass weight and female size and egg mass weight showed the best association between the parameters analyzed. In C. granulatus the female size (CW and female weight) was strongly correlated with the brood (number of eggs and dry weight) as well as reported by Luppi et al. (1997) in Mar Chiquita lagoon. According to Hines (1982), allometric limitations on space available for yolk accumulation in the body cavity appeared to be the main constraint on brood size.

Acknowledgments - We are very grateful to Dr. Maria Helena de Arruda Leme for the Portuguese translation of the abstract of this manuscript and the Ranger Corps, Daniel Mc Lean and Pablo Rojas, of the Refugio de Vida Silvestre Bahía Samborombón for their help during the samplings.

\section{References}

BOSCHI, EE., 1988. El ecosistema estuarial del Río de la Plata (Argentina y Uruguay). An. Inst. Cienc. del Mar y Limnol. Univ. Nac. Autón. México, vol. 15, no. 2, p. 159-182.

BOTTO, JL. and IRIGOYEN, HR., 1979. Bioecología de la comunidad del cangrejal. I. Contribución al conocimiento biológico del cangrejo de estuario, Chasmagnathus granulata Dana (Crustacea, Decapoda, Grapsidae) en la desembocadura del río Salado, Provincia de Buenos Aires. Seminario Latinoamericano de Ecología Bentónica y Sedimentología de la Plataforma Continental del Atlántico Sur. UNESCO, Montevideo, p.161-169.

CÉSAR, II., ARMENDÁRIZ, LC. and BECERRA, RV., 2005. Bioecology of the fiddler crab Uca uruguayensis and the burrowing crab Chasmagnathus granulatus (Decapoda, Brachyura) in the Refugio de Vida Silvestre Bahía Samborombón, Argentina. Hydrobiologia, vol. 545, no. 1, p. $237-248$

CONDE, J. E., TOGNELLA, MMP., PAES, ET., SOARES, MLG., LOURO, IA. and SCHAEFFER-NOVELLI, Y., 2000. Population and life history features of the crab Aratus pisonii (Decapoda: Grapsidae) in a subtropical estuary. Interciencia, vol. 25, no. 3, p. 151-158.

COSTA, MT., JANUÁRIO SILVA, SM. and NEGREIROSFRANSOZO, ML., 2006. Reproductive pattern comparison of Uca thayeri Rathbun, 1900 and U. uruguayensis Nobili, 1901 (Crustacea, Decapoda, Ocypodidae). Brasil. Arq. Biol. Technol., vol. 49, no. 1, p. 117-123.

ELLIOTT, JM., 1983. Some methods for the statistical analysis of samples of benthic invertebrates. Freshwater Biological Association. Scientific Publication, Freshwater Biological Association, UK, no. 25, 157p.

HINES, AH., 1982. Allometric constraints and variables of reproductive effort in brachyuran crabs. Mar. Biol., vol. 69, p. 309-320.

LEME, MHA., 2002. A comparative analysis of the population biology of the mangrove crabs Aratus pisonii and Sesarma rectum (Brachyura, Grapsidae) from the north coast of São Paulo State, Brazil. J. Crustacean Biol., vol. 22, no. 3, p. 553-557.

-, 2004. Fecundity and fertility of the mangrove crab Sesarma rectum Randall, 1840 (Grapsoidea) from Ubatuba, São Paulo, Brazil. Nauplius, vol. 12, p. 39-44.

LÓPEZ GRECO, LS. and RODRÍGUEZ, EM., 1999. Annual reproduction and growth of adult crabs Chasmagnathus granulata (Crustacea, Brachyura, Grapsidae). Cah. Biol. Mar., vol. 40, no. 1, p. 155-164.

LUPPI, TA., BAS, CC., SPIVAK, ED. and ANGER, K., 1997. Fecundity of two grapsid crab species in the Laguna Mar Chiquita, Argentina. Arch. Fish. Mar. Res., vol. 45, no. 2, p. $149-166$

MANTELATTO, FL. and FRANSOZO, A., 1997. Fecundity of the crab Callinectes ornatus Ordway, 1863 (Decapoda, Brachyura, Portunidae) from the Ubatuba region, São Paulo, Brazil. Crustaceana, vol. 70, no. 2, p. 214-226.

SPIVAK, ED., 1997a, Los crustáceos decápodos del Atlántico sudoccidental $\left(25^{\circ}-55^{\circ} \mathrm{S}\right)$ : distribución y ciclos de vida. Invest. Mar., vol. 25, p. 69-91. 
-, 1997b, Cangrejos estuariales del Atlántico sudoccidental $\left(25^{\circ}-41^{\circ}\right.$ S) (Crustacea: Decapoda: Brachyura). Invest. Mar. vol. 25, p. 105-120.

SPIVAK, ED., GAVIO, MA. and NAVARRO, CE., 1991. Life history and structure of the world's southernmost Uca population: Uca uruguayensis (Crustacea, Brachyura) in Mar Chiquita Lagoon (Argentina). Bull. Mar. Sci., vol. 48, no. 3, p. 679-688.

SPIVAK, ED., ANGER, K., BAS, CC., LUPPI, TA. and ISMAEL, D., 1996. Size structure, sex ratio, and breeding season in two intertidal grapsid crab species from Mar Chiquita Lagoon, Argentina. Nerítica, vol. 10, p. 7-26.

THURMAN, CL., 1985. Reproductive biology and population structure of the fiddler crab Uca subcylindrica (Stimpson). Biol. Bull., vol. 169, p. 215-229.

VIOLANTE, RA., PARKER, G. and CAVALLOTTO, JL., 2001. Evolución de las llanuras costeras del este bonaerense entre la bahía Samborombón y la laguna Mar Chiquita durante el Holoceno. Rev. Asoc. Geol. Arg., vol. 56, no. 1, p. 51-66. 